Article

\title{
Between Nationalism and Pragmatism: The Roma Movement in Interwar Romania
}

\author{
Petre Matei
}

Elie Wiesel National Institute for the Study of the Holocaust, 030167 Dacia, Romania; E-Mail: petre.matei@inshr-ew.ro

Submitted: 15 January 2020 | Accepted: 11 March 2020 | Published: 4 June 2020

\begin{abstract}
In the interwar period, for the first time in their history, Romanian Roma managed to organise themselves on a modern basis, by forming Roma associations and unions, and issuing their own newspapers and programmes. In an effort to define themselves, they became politically active, claiming and negotiating rights. In my article I analyse the context of the interwar Roma movement, how Roma leaders of the time saw themselves and their movement, what programme(s) they had, and how they tried to achieve their goals. This was a serious challenge: As they were not self-sufficient, they heavily depended on support from Romanian institutions, and hence they had to act with caution in order to avoid any hostile reactions from the Romanian majority. Overall, the discourse of Roma elites in interwar Romania ranged between: 1) a national approach directed inwardly, toward the Roma, for ethnic mobilisation purposes, including calls to unite in order to acquire their rights, efforts to combat ethnic stigmatisation, discussions on ethnonyms (Gypsy vs. Roma) or on the importance of Roma in Romania and worldwide, the beginning of a national/ethnic mythology (past, origin, enslavement, heroization vs. victimization, etc.); and 2) a pragmatic approach directed outwardly, toward Romanian authorities and public opinion; rather than a national minority, Roma leaders presented the Roma as a social category with specific needs, due to their historical legacy. Of these two, throughout the interwar period, pragmatism prevailed. Special emphasis was placed on the issue of social inclusion, and on identifying specific problems and solutions (i.e., better access to education, settlement, deconstruction of prejudices, etc.).
\end{abstract}

\section{Keywords}

Catholic Church; ethnicity; Orthodox Church; Roma; Romania

\section{Issue}

This article is part of the issue "Gypsy Policy and Roma Activism: From the Interwar Period to Current Policies and Challenges" edited by Elena Marushiakova (University of St Andrews, UK) and Vesselin Popov (University of St Andrews, UK).

(C) 2020 by the author; licensee Cogitatio (Lisbon, Portugal). This article is licensed under a Creative Commons Attribution 4.0 International License (CC BY).

\section{Introduction}

For the first time in their history, Romanian Roma managed to organise themselves on a modern basis during the interwar period, when they formed Roma associations and unions, developed various programmes, established their own newspapers, became politically active, and started to claim and negotiate their rights with various relevant actors.

However, the context in which this development occurred has long been unknown. There are several reasons for this situation. First, the Roma movement in Romania did not enjoy organisational continuity. Established in the 1930s, the last Roma association dating from this period was dismantled in January 1949. According to the Soviet model, the Roma were not acknowledged as an ethnic minority in communist Romania but seen rather as a social category. Consequently, until 1989, they did not enjoy educational, cultural, or political rights, and could not formally organise themselves, let alone establish links to the interwar movement.

Second, against this restrictive domestic background, the first mentions of the interwar Roma movement in Romania started to be made abroad a few decades later. In the new context created by the emergence in the 1970 s of the International Roma Union and the organisation of the first three World Roma Congresses in London 
(1971), Geneva (1978), and Göttingen (1981), some international Roma activists, in need of an illustrious precedent for their own movement, did not shy away from inventing it. For this purpose, they chose the movement in interwar Romania. A good example in this regard is an article written by Grattan Puxon, a prominent Roma activist and organiser of the London Congress of April 1971. According to Puxon, delegates from nine countries had gathered in Bucharest at an international congress with the motto 'The United Gypsies of Europe,' where they allegedly decided to set up Roma organisations in each country. In order to achieve an efficient coordination of the Roma from different states, they made the decision to set up a permanent commission composed of 30 members (including international delegates) to prepare a second congress, in Paris or elsewhere (Puxon, 1979, pp. 291-292). However, these references had little in common with the actual congress. Starting from a real but relatively modest Roma Congress that took place in October 1933 (and definitely without the international guests and meaning mentioned above), Puxon came to describe his own project concerning the international Roma movement in the 1970s, which he projected onto the past. The real event merely served as a pretext, and the context of the interwar Romanian movement was completely ignored.

Third, another reason for not properly dealing with the Roma movement was the conflicting attitude toward Jews. While many Roma activists are nowadays searching the past for similarities with the Jews (explainable by the discriminatory and genocidal treatment endured by members of both groups during the Second World War), these cannot be easily found in interwar Romania. The Roma were not a matter of concern for the nationalist parties, otherwise fiercely anti-Semitic. There were even agreements and collaboration occurring under certain conditions between Roma organisations and those parties, such as the fascist Iron Guard, whose leader, Corneliu Zelea Codreanu, promised help for organising the first Roma congress in October 1933, and the National Christian Party in 1937. Moreover, some Roma activists expressed anti-Semitic ideas in the 1930s (Matei, 2011, pp. 31-35). Practically, instead of a narrative easily suitable for current needs, there is also an uncomfortable truth that needs to be confronted. On the other hand, recent research explored the interwar Roma movements (Klimova, 2002, 2005; Marushiakova \& Vesselin, 2017). Despite containing meritorious references, they do not focus however on the Romanian Roma movement. Neither did the few academic studies dealing so far with the interwar Roma movement in Romania exceed the limitations of a rather descriptive approach. For example, more attention was paid to the personal features of the Roma leaders, or to 'juicy' episodes such as the partnership with the antiSemitic National Christian Party in 1937 (Achim, 2010, pp. 93-97), and less to the context that made possible this distinctive evolution.
One should resist the temptation to oversimplify or to project current expectations onto the past. Compared to the present-day situation, the opportunities available to the interwar Roma activists were much scantier and hence their movements depended heavily on circumstances relating to different national contexts. There were interesting commonalities between them, but also differences that should not be neglected. As the Roma movement risks being easily misunderstood if taken out of its original context (Marushiakova \& Vesselin, 2000, 2017), the present article tries to address this situation in Romania and contribute to a better knowledge of the circumstances that made possible this interwar movement. Moreover, as it offers terms for comparison, these can also help to better contextualise and understand how the Roma movement in Romania evolved in the last century, and the extent to which it differed from other interwar Roma movements. These differences and similarities lie however beyond the scope of this article.

The main sources used for this article are relevant archival documents and the interwar press. With regard to the archival sources, we distinguish between 1) published collections of documents about the Roma assemblies in Transylvania in 1919 (Matei, 2013) and the Roma organisations between 1919 and 1944 (Nastasă \& Varga, 2001) and 2) unpublished documents (from different archival holdings available at the Central National Historical Archives in Bucharest) produced especially by the Romanian Ministry of Interior and other law enforcement agencies. As for the interwar press we distinguish between 1) the Roma newspapers published between 1933-1941 (Timpul, O Rom, Neamul Tigănesc, Glasul Romilor, Foaia Poporului Romesc, Tara Noastră: Ediție specială săptămânală pentru Romii din România) and 2) non-Roma newspapers covering the Roma movement. As these different sources offer valuable insights into the Roma movement and how it was perceived by different actors, they were analysed in a comparative manner, both diachronically and synchronically.

In an effort to analyse the context of the interwar Roma movement, the present article is divided as follows: First, we briefly present the most important Roma organisations and the factors that contributed to the emergence of the interwar Roma movement. Special attention will be dedicated to the larger room for manoeuvre available to Roma after the First World War, when their movement was actually encouraged by different Romanian actors (various authorities, political parties, or churches). These actors had their own goals, primarily to consolidate their own ethnic and confessional positions, especially in the provinces recently acquired by Romania after 1918. These had significant ethnic minorities that were perceived as competitors against which the Romanian state-builders tried to play off the Roma movement. Second, we analyse interwar Roma discourses in Romania, seeking to answer the following questions: How did Roma activists see themselves and their movement? What was the nature of the problems 
their movement wanted to address and what solutions did they envisage? What was their strategy and how did their discourses evolve in the 1930s?

\section{Interwar Roma Organisations: An Outline}

In this section, following a brief description of the main Roma organisations that were active on a national level, we present the factors that contributed to the emergence of this movement. During the interwar period, several types of Roma organisations coexisted: 1) traditional organisations specific to a small segment of nomadic Roma; 2 ) relatively modern organisations (be they mutual aid societies for burials, associations of Roma musicians, or small town societies such as înfrățirea Neorustică (New Peasant Brotherhood), that were initially uncoordinated and spatially and professionally limited; and 3) modern organisations aspiring to represent all the Roma in Romania (starting in 1933). The idea of uniting all Roma in a single ethnic organisation exceeded the limited character of the previous organisations to promote the interests of certain categories of Roma. After 1933, in Romania, there were several such central organisations that competed against one another.

The first nationwide Roma organisation was the General Association of the Gypsies in Romania, created in April 1933 at the initiative of the Orthodox Archimandrite Calinic I. Popp Șerboianu. The latter came in contact with the committee of the older Junimea Muzicală (Musical Youth; a musicians' association in Bucharest) and formed a provisional committee. However, in September 1933, almost right from the start, the General Association of the Gypsies in Romania was sabotaged by its former Secretary General, G.A. Lăzurică, who accused Șerboianu of intending to convert the Roma to Catholicism. Concerned about this prospect, the Romanian Orthodox Church encouraged Lăzurică to establish an Orthodox alternative (the General Union of Roma in Romania). After just a few months, in May 1934, Lăzurică was also forced to resign from the position of President of the General Union of Roma in Romania by Gheorghe Niculescu, who replaced him. Subsequently, a fight for legitimacy ensued between these leaders. There were even cases when local Roma from the same town were divided into branches of rival organisations. Lăzurică's and Șerboianu's activities diminished until the summer of 1937, when they benefited from an electoral agreement with the National Christian Party. In March 1937, the police noted that the Roma in Romania were grouped into three major organisations: the General Association of the Gypsies in Romania (Șerboianu), the Roma Citizens Organisation (Lăzurică), and the General Union of Roma in Romania Association, led by Gheorghe Niculescu (Nastasă \& Varga, 2001, p. 117). However, the most important interwar Roma organisation remained the General Union of Roma in Romania Association, which, between 1934 and 1941, had its own newspaper, Glasul Romilor, and organised branches in numer- ous towns and villages, holding meetings and congresses. In addition to its missionary activity, it set up a litigation that provided free services to the Roma, dispensary and maternity wards, interceded with the authorities to obtain authorisations for the nomads to freely practice their trades, etc. (Achim, 1998, p. 130).

Three factors contributed to the emergence of the interwar Roma movement. First, the gradual inadequacy of the traditional Gypsy trades in the context of modernisation and industrialisation. The Roma crafts, formerly so necessary to traditional Romanian society, were increasingly less in demand (Achim, 1998, pp. 123-124). These transformations led to efforts to find solutions, such as putting together various forms of self-help. These grew from strictly socio-professional into larger ethnic organisations claiming to represent all Roma.

Second, increased social mobility caused by better literacy, economic progress, land received through the agrarian reform enacted after the First World War, etc. While until the interwar period the rule was that successful Roma assimilated into mainstream society, starting from the 1920s some of them became interested in representing the Roma and tried to improve their situation by creating Roma organisations.

Third, enlarged room for manoeuvre after the First World War, whereby better opportunities to collaborate with different entities appeared (political parties, law enforcement agencies, the Orthodox Church, or simply Romanians, who competed against other ethnic groups, especially in disputed areas such as Transylvania, and needed any support, including that of Roma). The new Roma leaders became aware of these possibilities and learned to use them. In the following section, special attention is dedicated to this factor, the larger room for manoeuvre available to the Roma movement, which was encouraged by the Romanian establishment for its own purposes.

\subsection{The Roma Movement and Other Minorities}

Unlike pre-war Romania, which was smaller in terms of both surface and population $\left(138,000 \mathrm{~km}^{2}\right.$ and $7,900,000$ inhabitants), but was ethnically and confessionally homogeneous, interwar Romania had doubled its surface $\left(295,000 \mathrm{~km}^{2}\right)$ and population, but lost its ethnic and denominational homogeneity. According to the 1930 census, it had a population of 18,000,000, of which the Romanians represented $71.9 \%$, with the remaining nearly $30 \%$ consisting of ethnic minorities (Hungarians $7.9 \%$, Germans $4.1 \%$, Jews $4 \%$, etc.). The Roma were only in the eighth place, with 262,501 people (Scurtu \& Dordea, 1996, p. 468). Some minorities (especially the Hungarians, Germans, and Jews) were more urbanised and better educated and economically positioned than the Romanians, a predominantly rural population. Therefore, state resources were used to consolidate the ethnic Romanians against what were perceived as competing minorities. This ethnic rivalry, es- 
pecially in Transylvania (between Romanians, Germans, and Hungarians), contributed to the mobilisation of the Roma, as the latter was seen as more of a solution than a problem. Already before the First World War, there had been a closer relationship between Roma and Romanians in Transylvania. Both groups lived predominantly in rural areas, so the Roma, when assimilated, were prone to become Orthodox or Greek Catholic, both seen as 'Romanian' confessions. After 1918, this turned into a valuable asset which could serve as a starting point for the ethnic mobilisation of the Roma. The newly installed Romanian authorities started to show interest in the Roma's potential to help in places where the Romanians' positions were rather precarious, and consequently tried to play off the Roma movement against other minorities. The Roma leaders were aware of these concerns and tried to use them to their own advantage, as they could count on an encouraging reaction from the Romanians and their administration (Matei, 2011). Already on the occasion of the Roma assemblies in Transylvania in April 1919, the participants proved to be pragmatic and demanded social and ethnic rights in exchange for recognising Transylvania as part of Romania, and declared themselves loyal to the new state while practically condemning the so-called "Hungarian barbarians" that Romania was fighting in 1919 (Matei, 2013, p. 448). After 1933, when Roma established their national organisations, this cooperation became stronger. For example, an article published in Glasul Romilor in 1938 stated:

Most of the Magyarized Roma understood us. Now they say they are also of Romanian citizenship and nationality. Their children are no longer attending minority schools.... Romanian brothers, if you love us, we will know how to carry out the work we are going to do from now on in the service of the Romanianization of the Magyarized Roma. (Stan, 1938, p. 4)

A similar policy was followed also regarding the local sași (German-speaking Saxons). In September 1942, at the time of the Roma deportation to Transnistria, there were cases when the Transylvanian Romanian population condemned these deportations on the grounds that they weakened the Romanians' position against the sași:

The Romanians, strengthened by the number of Gypsies, were able to secure most votes during the last elections and thus get leadership positions vis-à-vis other minorities. The measure taken recently alienated the Gypsies from their loyalty to the Romanian element. (Achim, 2004, p. 214)

\subsection{The Roma and the Orthodox Church}

A similar pattern was encountered in the Roma's relationship with the Romanian Orthodox Church. After 1918, Romania was no longer religiously homogeneous, and the Romanian Orthodox Church, formerly dominant in the Old Kingdom, was confronted with numerous other denominations. In this context, the Romanian Orthodox Church showed a strong interest in the Roma movement, as it was concerned about their potential conversion to Catholicism.

In his initiative of organising the Roma in 1933 and in his public statements, Șerboianu appeared as a Roma Orthodox prelate. In fact, he was an ethnic Romanian very familiar with the Roma language and customs, about which he had written a book in which he ascribed to them features such as lying, theft, begging, child kidnapping, and even cannibalism (Șerboianu, 1930, pp. 60-74). In 1933, when questioned by the police, Șerboianu admitted he was not a Roma but had claimed this origin to gain their trust, so that he could organise them (Nastasă \& Varga, 2001, p. 102).

What troubled the Romanian Orthodox Church even more was that Șerboianu had recently converted to Catholicism. The Romanian Orthodox Church suspected Șerboianu could use the movement he had just established in order to also convert the Roma (by then largely Orthodox), and reacted accordingly. Thus, the Patriarchate decided to support an Orthodox movement (led by Lăzurică; Matei, 2010). According to a police report dating from 30 September 1933, Lăzurică was helped by the Orthodox Church:

To counterbalance the action of the General Association of Gypsies from Romania under the leadership of Archimandrite Calinic I. Popp Șerboianu, who seeks to convert Roma (Gypsies) from Orthodoxy to the Uniate Church....Support of the Patriarchate consists in the fact that the Patriarch himself, seeing with good eyes the action of Lăzurică, urged him to fight further for the creation of the Roma Union. (Nastasă \& Varga, 2001, p. 101)

Not only did the Orthodox Church finance the Roma congress on 8 October 1933, printed the Roma manifestoes and statutes, and rented the venues, but it also interceded with different authorities on behalf of Lăzurică, making sure he would get the necessary approvals for the congress, while simultaneously trying to obstruct Șerboianu's organisation (Nastasă \& Varga, 2001, pp. 104-105). Another police note of 7 October 1933 showed that the debut of the General Union of Roma in Romania was quite promising, as the Union was:

Under the protection of His Holiness, the Patriarch of Romania, who gave and promised to Lăzurică all his support for the congress, telling him that he would allocate also a monthly grant of 10,000 lei for the development of the Gypsy association. (Nastasă \& Varga, 2001, p. 107)

This was, in fact, the so-called International Congress of the Roma in Bucharest referred to by Grattan 
Puxon, and we can see it differed considerably from Puxon's description.

The Patriarch reiterated his support for the General Union of Roma in Romania also after the Roma congress of 8 October 1933. In the following months, Lăzurică made efforts to strengthen the General Union of Roma in Romania even among the Roma from Transylvania. As he did not have the necessary financial resources to allow him such freedom of action, Lăzurică tried to persuade the Orthodox Church to help. In February 1934, at Lăzurică's request, the Patriarchate issued a missionary card to Lăzurică, allowing him to perform Orthodox missionary work among Roma throughout the country:

As we consider it in the public interest to remove the influence the papist agents have upon Roma...we approve the request of Mr. Gh. A. Lăzărescu (Lăzurică) to be given this document as an Orthodox missionary so that he could go to his confreres, members of the General Union of Roma from all over the country. This assignment of Orthodox missionarism among the Roma is brought to the notice of the other Holy Hierarchs in our Romanian Orthodox Church. (Lăzurică, 1937a, p. 3)

This document legitimised Lăzurică to the relevant authorities and allowed him to enjoy the benevolent help of the priests in the parishes with a significant number of Roma. Moreover, the Orthodox Church also offered Lăzurică a sum of money, which, although modest, was intended to finance his travels aimed at converting Roma to Orthodoxy. Interestingly enough, in Transylvania, where he organised several meetings and set up the General Union of Roma in Romania branches, Lăzurică started to realise that the Orthodox Church was not as useful as it was in Bucharest or the Old Kingdom, where most inhabitants were Orthodox. Far from being a cohesive element offering legitimacy and resources for Roma mobilisation, as he had hoped, Orthodox missionarism could, on the contrary, alienate both the local Roma and non-Roma (Romanians included) who belonged to other denominations:

Many Roma from Transylvania were making remarks to me that, although they appreciated me and agreed with the cultural, social, and moral program of the Union, they cannot accept to convert to Orthodoxy, when they are Catholic or Uniate [Greek-Catholic]. In other words, I was losing the Roma sympathies and adhesions to my Union because of my Orthodox missionarism....In Transylvania I was rejected by all the Catholic and Uniate priests, by all the politicians who were part of these cults, when I could have enjoyed their support if I had not been an Orthodox missionary. (Lăzurică, 1937a, pp. 3-4)

In the spring of 1934, Lăzurică was forced to resign in favour of Gheorghe Niculescu, former Vice-President of the General Union of Roma in Romania and a well-todo flower merchant in Bucharest. Throughout the summer of 1934, there was a relative balance between Lăzurică and Niculescu, but in the end Niculescu prevailed and the Romanian Orthodox Church reoriented itself to the more efficient organisation he presided over (the General Union of Roma in Romania Association).

Generally, this was a win-win situation for both the Roma movement and the Church. With the Romanian Orthodox Church's help, the Roma movement obtained a certain moral legitimacy, being offered a pretext to organise the Roma from different communities, while benefitting from the support of local or central officials who participated in the events sponsored by the Church. Religious guests (priests, bishops, metropolitans, even the Patriarch Miron Cristea) and laity (mayors, prefects, parliamentarians, even ministers) came to such events, thus contributing to the consolidation of the General Union of Roma in Romania Association. As for the benefits to the Romanian Orthodox Church, this cooperation not only put an end to the potential conversion to Catholicism of the Roma, but also allowed it to go on the offensive, converting non-Orthodox Roma to Orthodoxy. Such actions were carried out not only in Transylvania, but also in southern Romania where, in the 1930s, there were collective baptisms of some groups of Muslim Roma (Copoiu, 1996, pp. 7-9).

\subsection{The Roma and Political Parties}

Another factor that favoured the emergence of the Roma movement was the electoral law of 1918, which gave the Roma the right to vote. This became an important stimulus for the future organisation, as political parties became interested in their votes. However, the beginning was difficult and the initial impact on Roma was low. As a term of comparison, we use the letter that the mother of the future statistician and demographer Sabin Manuilă, then in the USA as a Rockefeller scholar, sent to her son in February 1926. Writing to him about the local elections, she reproduced the words of the maid:

Madam, big surprise in our Gypsy neighbourhood. Some gents came to us last evening and told our Gypsies to vote for them, 'cause they would buy them drinks for 1,000 lei but we refused to go for a drink and we all spread, 'cause they were liberals and we did not want to. ("Scrisoare," 1926)

Buying votes with beverages, food, firewood, money, etc., was a frequent practice during elections. However, things tended to change after 1933, which was a turning point not only in the way Roma organised, but also in the way they were seen by the political parties. The latter could finally negotiate directly with some Roma leaders, who gradually learned that they were believed to be capable of guiding the Roma voters. Consequently, in an effort to capitalise on this interest from the politi- 
cal parties, Roma leaders started to claim that they could really mobilise the hundreds of thousands of Roma voters. This situation provided the Roma organisations and leaders with a certain clout. In order to get votes, one had to offer something in return. Although uneven, a partnership emerged. Consequently, the peak moments of the interwar Roma movement in Romania were actually represented by the electoral campaigns of 1933 and 1937, when the Roma organisations were being courted by politicians.

The Roma organisations were pragmatic and collaborated relatively well with the political parties. For example, the General Union of Roma in Romania Association, the longest-standing organisation (1934-1941, 1946-1948), although apolitical according to its own statute, cultivated, in fact, close ties with the ruling parties: between 1934 and 1937 with the National Liberal Party, between 1938 and 1940 with the National Renaissance Front, and, after the war, with the Romanian Workers' Party.

Several articles written in 1937 by G. A. Lăzurică offer important insights into the political parties' interest in Roma votes and its impact. Lăzurică wrote bitterly about his own political experiences with the National Liberal Party:

We have struggled for five years to realise our programme, appealing to all the competent forums and all the representatives of the political parties, without being listened to. The political parties we addressed asked first for our votes and promised us they would fulfil the Roma wishes only after Roma voted for them. In the interest of the cause, I launched manifestoes in the middle of the elections for the Chamber and the Senate, urging the Roma to give their votes to the National-Liberal Party, which governs the country today. But after the votes were given, this party closed its doors and ostracised us. (Lăzurică \& Șerboianu, 1937, p. 1)

Disappointed with the National Liberal Party, Lăzurică and Șerboianu signed a political agreement with the farright National Christian Party in 1937. They promised to mobilise the votes of the Roma (which they exaggerated to 125,000 ) in exchange for the promise that the Roma would have representatives on the National Christian Party lists in elections for county, communal, and labour council chambers. In addition, the National Christian Party made available to them the newspaper Țara Noastră, which issued a weekly edition for Roma. The arrangement gave hope to the two leaders that many of the Roma issues would be resolved:

Since the Roma will have their representatives in county and communal councils, as well as in the chambers for labour, they will no longer be ostracised. Your fair complaints will be resolved. We will have a centre, kindergartens, recreational camps at the seaside and in the mountains, schools for Roma musicians, libraries, athenaeums; the entire program announced by us will be implemented. We will not compete with foreigners in our trades as masons, builders, blacksmiths, musicians, porters, etc. (Lăzurică, 1937b, p. 6)

Thus, the collaboration of Roma organisations with various parties (the anti-Semitic National Christian Party included) was more complex and should not be viewed simplistically outside its proper context and reduced to this anti-Semitic episode.

Shortly thereafter, in 1938, political parties were dissolved following the establishment of the dictatorship of King Carol II. A police report from July 1940 stated that the organisations of both Niculescu and Lăzurică had been supported by political parties, the first by the National Liberal Party and the second by the National Christian Party:

In 1933 a movement for organising the Roma began, encouraged by different political parties for electoral purposes....With the abolition of political parties and the disappearance of the electoral interest of those who supported and subsidised them, the activity of these associations stagnated. (Nastasă \& Varga, 2001, pp. 255-256)

The interests of political parties in getting (Roma) votes boosted the Roma movement in a manner similar to the mutually advantageous relationship established with the Orthodox Church.

\section{Interwar Roma Discourse: Problems and Solutions}

In the following pages we outline the main features of the discourse of interwar Roma elites, trying to answer questions such as how the Roma leaders of the time saw themselves and their movement, what programme they had, and how they tried to achieve their goals.

The Roma activists declared the nature of their problems to be mostly social: 'state of backwardness,' chronic poverty, illiteracy, culminating with the contempt they experienced from the majority population. The 1933 programme of the General Association of the Gypsies in Romania (maintained by the other Roma organisations) took its cues from the inferior status of the Roma and had two components: cultural (with an emphasis on education, from kindergarten through vocational schools, material support for poor students, and evening courses for adults to a popular university, national museum, a newspaper, etc.) and social (legal assistance, free medical assistance for Roma, land for Roma to build their houses on, payable in instalments, settling down the nomads, mutual aid organisations, etc.; Nastasă \& Varga, 2001, pp. 94-99).

However, to understand the Roma discourse, one must consider the specific context of the interwar period, when the Roma movement depended exclusively on the 
Romanian authorities for resources, legitimacy, and approval. Roma tried to identify and exploit opportunities and niches. Thus, it was vital to get along well with the authorities that agreed to help, but only under certain conditions. Only those Roma organisations that were credible to the Romanian establishment had chances of success. As such, the Roma elites resorted to a discourse meant not to antagonise the Romanian authorities, but to convince that the Roma movement deserved to be tolerated and supported due to its usefulness. Therefore, the Roma leaders showed loyalty to the Romanians, the Church, and the monarch, and they were willing to help convert the Roma to Orthodoxy, assimilate the Roma in multi-ethnic areas to the Romanian majority and mobilise them in electoral contexts. In addition, they tended to present themselves as a group whose problems were social rather than ethnic and their movement as a means to solve their own (social) problems, rather than to create additional (ethnic) difficulties for Romanians.

Overall, the interwar Roma elites' discourse varied according to the targeted recipients: the Romanian establishment, which they hoped to sensitise and make aware of the Roma's plight, and Roma masses that they sought to mobilise.

The Roma leaders insisted on their loyalty to the Romanians and made constant efforts to avoid being perceived as another minority. They described themselves as good Romanians, assimilation into mainstream society was apparently encouraged, and they argued they had the same 'Romanian faith' (as Orthodox or Greek-Catholics), that they were keepers of the Romanian customs and songs, faithful to the Dynasty and the (Orthodox) Church, lived for centuries among Romanians and throughout this long history no example of a Roma traitor was found, etc. All these arguments were used to reduce any risk of being suspected of hostility toward Romanians. The text of a Roma leader from Oltenia writing in January 1934 is illustrative:

They should not be considered as a minority. They did not pursue, either in the past or today, a minority policy. They do not form a political or religious minority. They are in a special situation and with tendencies of voluntarily assimilating into the great mass of the dominant people. What their leaders demand, and what the Roma in Romania also want, is only having their citizenship rights respected, that they are eligible to as perfectly loyal citizens of the Romanian state, as well as a deeper and wiser understanding of the right to a better life, to get out of the deplorable situation in which they are. (Nicolăescu, 1934, pp. 1-2)

Sometimes they were even more explicit and used the Romanian nationalist rhetoric against other minorities. They proceeded this way precisely in order to gain a positive image, as they insisted on being different from the disloyal Transylvanian Hungarians, the "snaky Jews" (with their Alliance Israélite Universelle), the
Bulgarian comitagii (insurgents) from southern Dobruja, etc. ("Un milion," 1934, p. 1). According to this argumentation, despite their allegedly treacherous behaviour, those minorities continued to unjustly receive better treatment from the Romanian authorities, which should have instead paid more attention to their loyal Roma fellow citizens. Roma could but hope for a change of the state's attitude toward them. While this strategy is difficult to understand if judged by today's standards, such opportunism appears understandable in its proper historical context.

In addition to the Romanians, the other target group of the Roma elites' discourse were the Roma themselves. Here, the discourse's role was to create a sense of belonging, to modernise the Roma, and to create an alternative to assimilation. However, this Roma nationalism was generally subordinated to pragmatism and tempered by the fear of provoking the hostility of the majority, on whose good will the Roma movement depended. Efforts were made to combat the ethnic stigma and instil pride in being Roma by different means, such as by promoting the ethnonym 'Roma' (Matei, 2012), invoking their resilience, the illustrious Indian origin, slavery, manumission, the sacrifices made for Romania which entitled them to a better treatment, etc. While the positive arguments were supposed to create a sense of belonging (by talking about the achievements, qualities, and especially about the potential of the respective ethnic group), the negative ones channelled frustration by explaining the current plight through their horrific past.

Some Roma leaders started already in the 1930s to create a Roma national mythology, talking about a distant past with courageous and glorious Indian ancestors. Consequently, the Roma were presented as a people full of vitality, whose past suggested a better future:

We, the Roma, are of the Aryan (Indo-German) race. We lived freely, possessing a rich and large land. We had brave rulers under whom we fought victorious battles with countless people....We, the Roma, speak the Sanskrit language, one of the oldest and richest languages, from which the Slavic, German, Latin, and Greek languages derive, as the philologists have shown. (Lăzurică, 1938, p. 2)

However, unlike today, the efforts to disseminate this information about their Indian origin were relatively few, and their impact was reduced. The emphasis at the time was not placed on the distant Indian origin, but on more pressing and recent elements, capable of explaining the precarious status of the Roma: 1) slavery, 2) the state's lack of interest in the social plight of Roma after manumission, and 3) the ethnic stigma and its consequences, particularly the assimilation of modern Roma elites, thus depriving the Roma of potential leaders.

The slavery argument can be seen as part of a larger discourse, centred around the victimization-guilt tandem. It was aimed at strengthening the sense of iden- 
tity by finding explanations and solutions for marginalisation. However, there are significant differences between how the Roma ethnic entrepreneurs in the 1930s and contemporary Roma activists perceive(d) slavery. This can be explained by the very different contexts in which they acted. In contrast to the present-day situation, when there are better opportunities for an ethnic Roma project, thanks to the existence of better-prepared, more influential elites, but also to the larger space of manoeuvre (within the European Union), interwar Roma leaders were vulnerable and could not afford to ignore the Romanian nationalist susceptibilities. Consequently, there was a certain degree of self-censorship in Roma discourse. Thus, while their current plight was explained to a certain extent also by their experience of slavery, interestingly enough, the interwar Roma discourse, unlike the one today, presented a lighter version of this slavery. While talking about Roma slaves, they hesitated to name the enslavers. Thus, the interwar slavery discourse was not as demanding and radical as the one today. For example, when talking in 1935 about their enslavement, one Roma activist considered it as a rather harmless, common social reality of the past:

In Romania they came around the 14 th century...they were welcomed in Romania, where they remained in peace as slaves on the estates of the Romanian boyars....No one should be surprised that the Roma became slaves in Romania, because back then neither the Romanians nor other people in Europe enjoyed a better fate. (Genicol, 1935, p. 4)

Similarly, only certain categories were considered responsible for this enslavement, and guilt was externalised (placed on Greek monks or boyars, or Greek Phanariotes, very rarely on the Orthodox Church and never on the Romanian people as a whole; "Desrobirea," 1939, p. 2).

Two other, more recent factors were emphasised in the interwar Roma discourse: the Romanian state's neglect since manumission and the assimilation of its elites. First, the Roma leaders considered that since manumission no one had thought about the fate of the Roma, who had been completely neglected. Already in 1930, Șerboianu wrote the following: "Although liberated, poverty imposed new servitude on them, making them, with very few and small exceptions, veritable pariah that everyone exploits or forces to resort to every possible means to lead a better life" (Șerboianu, 1930, p. 57). The manumission, although appreciated, was not considered a panacea (Lenghescu-Cley, 1934, p. 1). It should have been followed by guidance from the state, but this did not happen: "This great deed also had its shortcomings; they [Roma] were given the freedom without offering them the necessary means to make use of it. The people remained the same: devoid of culture" (lonescu, 1935, p. 3). In short, it was argued that the situation of the Roma had not radically improved after their 19th century manumission, as poverty, lack of education, and marginalisation constituted a metaphorical new form of bondage ("Întrunirea," 1933, p. 5).

Another problem was the assimilation into mainstream society that deprived the Roma of their potential elites. One hoped that by reversing the phenomenon these promising Roma would have promoted Roma emancipation and subsequently the Roma, organised in a modern movement, could have finally enjoyed the support of the state. The discourse concerning these assimilated individuals was ambivalent. On the one hand, they were invoked to encourage others (serving as living proof of the Roma's innate potential). On the other hand, they were criticised for leaving their Roma community behind:

After manumission, with all the lack of guidance and with all the needs that they had to deal with, the past generations of our people managed to offer important personalities, but the majority remained backward, lacking moral and material guidance. Another reason why our people could not prosper is that many sons of our nation who managed to reach higher levels of social status forgot their origin, quite often denying it tenaciously. (Anghel, 1939, p. 2)

However, this criticism was seldom overt. Roma activists could not afford to be too vehement. Otherwise, the contradiction in their discourse would have become visible. It would have been strange to accuse some Roma of assimilating, given that the Roma movement, dependent on Romanian support, insisted on not representing an ethnic minority: "Could we shout at them: 'Renegades, you are claiming to be pure Romanians while you are clearly Gypsies?!' It would mean to dismantle our own argument, that we are Romanians, not a minority" ("Renegații," 1937, p. 5).

The negative discursive elements (slavery, neglect from the state, assimilation of potential elites) were not meant to discourage but rather to exorcise, by identifying the causes for their contemporary difficult situation. The suffering endured throughout their history was invoked for current identity needs. This victimization was not a phenomenon specific to the Roma, but a relatively effective way, to which many others had resorted before, to explain and channel certain frustrations. However, this discourse lacked both coherence and practical ways of delivering it to the majority of Roma, who were mostly illiterate and thus difficult to mobilise.

The following section addresses the main solutions envisaged by the same Roma activists. These were: 1 ) the Roma movement; 2) schooling; and 3) representation of the Roma in the local administration, especially where they formed a significant part of the population. The Roma movement was seen as a response to Roma problems, which could be solved only through solidarity and self-organising. Gheorghe Niculescu, an important Roma leader, wrote in August 1935: "If we research the his- 
tory of each nation, we will find that a better status could be achieved only by union of all....Only one thing is requested: union, union, and again union" (Niculescu, 1935, p. 3). Marin Simion, leader of the Roma in Oltenia, was even more explicit: neglected and derided so far, the Roma had to unite within the General Union of Roma in Romania Association:

Everyone's duty is to help create this beginning of a conscience, which can manifest itself only as a new power in our state, and not as a minority....Through their union, an organism would be created which could not be ignored anymore and their claims will not remain just a piece of paper. (Simion, 1934, p. 1)

The interwar activists considered illiteracy to be one of the most serious problems affecting Roma. As the traditional trades of the Roma were increasingly fading, schooling was seen as a solution. Moreover, it was considered that the precarious state of instruction affected not only individual Roma, but also the Roma as a group. In the fall of 1933, one activist stated: "The Gypsy nation is surrounded by the heavy chains of lack of culture. We need a key to open the locks that hold these chains. This situation has to stop" ("Întrunirea," 1933, p. 5).

The Roma organisations often called for this situation to be remedied by encouraging Roma pupils to attend school and asking the state for certain facilities. For example, in February 1934, Lazăr Naftanailă from Făgăraș asked the nomadic Roma to settle down and send their children to school and urged the sedentary Roma to "try to send their children to higher schools so that we can prove that the Gypsy people are reliable and that their best children are not at all inferior to the children of other peoples" (Naftanailă, 1934, p. 1). Sending their children to school was one of the main recommendations that the organisations frequently made in their own newspapers. In such an article, we find the following: "To send their children to school....To respect the church and school representatives, taking part in all the cultural events that these representatives undertake in villages and cities" ("Ce trebuie să facă un rom," 1934, p. 2). At the same time, the state was asked to help remedy this situation. It was considered that Roma's lack of instruction was also due to the school system, which neglected them. Once at school:

Roma children were, for the most part, merely the object of amusement of their colleagues and thus alienated from the place that was supposed to enlighten them. Hence, deprived of spiritual education, it is natural that they are at this level. (Niculescu, 1937, p. 1)

In a more detailed article from 1938, where the disappearance of the old trades, which could no longer compete with factory products, was lamented, it was argued that the only solution for the new generations was schooling:
Our youth shall be guided to school. Thus we will fight against illiteracy, asking those in charge to give us all their support....The only reason we are asking for this help is to combat illiteracy and thus give the chance to the better ones to attend secondary and university courses, and to those with an application for trades, industrial high school courses or arts and crafts schools. Thus, also from the ranks of our Roma children, civil servants, lawyers, doctors etc. will rise. (Pantazescu, 1938, p. 3)

\section{Conclusion}

The interwar Roma movement was confronted with serious difficulties. As they were not self-sufficient, they depended on support from Romanian institutions for resources, legitimacy, and approval, and hence they had to act cautiously in order to avoid any hostile reactions from the Romanian majority. Good collaboration with the Romanians authorities was vital and proved mutually advantageous, as the Romanian authorities themselves considered using the Roma movement in order to solve other problems. However, the partnership was highly asymmetrical. Unable to imperatively claim ethnic rights, the Roma focused instead on sensitising the Romanians, through the repeated invocation of their loyalty. Overall, the discourse of interwar Roma elites ranged between a national approach directed inwardly, toward the Roma, for ethnic mobilisation purposes, and a pragmatic approach aimed outwardly, toward Romanian authorities and public opinion.

However, throughout the interwar period, pragmatism prevailed. Special emphasis was placed on the issue of social inclusion. Interwar Roma activists stood little chance of disseminating a convincing identity narrative to the Roma masses. Neither the context nor the necessary means existed at the time. Even now, despite much better opportunities, one cannot yet talk about a homogenous Roma identity discourse.

\section{Acknowledgments}

I would like to thank the Academic Editors and the two anonymous reviewers for their insightful comments. I would also like to thank Raluca Bianca Roman and Raul Cârstocea for offering invaluable feedback on earlier drafts and for their help with the proof-reading of the entire text.

\section{Conflict of Interests}

The author declares no conflict of interests.

\section{References}

Achim, V. (1998). Tiganii în istoria României [The Gypsies in Romanian history]. Bucharest: Ed. Enciclopedică. Achim, V. (2004). Documente privind deportarea ți- 
ganilor în Transnistria [Documents concerning the deportation of Gypsies to Transnistria] (Vols. I and II). Bucharest: Editura Enciclopedică.

Achim, V. (2010). The Roma organizations and their relations with the Romanian politics in the 1930s. In D. Berindei (Ed.), Nouvelles études d'histoire, vol. XII: Publiées à l'occasion du XXIe Congrès International des Sciences Historiques, Amsterdam, 2010 [New Historical Studies, Vol. XII: Published on the occasion of the 21st International Congress of Historical Sciences, Amsterdam, 2010] (pp. 85-102). Bucharest: Editura Academiei Române.

Anghel, L. (1939, June 7). Frați Romi [Roma brothers]. Glasul Romilor, 5(13), p. 2.

Ce trebuie să facă un rom [What a Roma should do]. (1934, September 23). O Róm, 1(1), p. 2.

Copoiu, P. (1996). Rromane paramica: Povești țigăneşti [Gypsy tales]. Bucharest: Ed. Kriterion.

Desrobirea [The manumission]. (1939, June 7). Glasul Romilor, 5(13), p. 2.

Genicol. (1935, October 21). Un iubitor al Romilor: M. Kogălniceanu 1817-1891 [A friend of the Roma: M. Kogălniceanu 1817-1891]. Foaia Poporului Romesc, 1(1), p. 4.

Întrunirea Asociației țiganilor din România [The assembly of the Association of Gypsies in Romania]. (1933, October 17). Dimineața, 29, p. 5.

lonescu, N. S. (1935, August). A sosit ceasul deșteptării [The hour of awakening has come]. Glasul Romilor, 2(1), p. 3.

Klimova, I. (2002). Romani political representation in Central Europe: An historical survey. Romani Studies 5, 12(2), 103-147.

Klimova, I. (2005). The development and institutionalization of Romani representation and administration (part 2): Beginnings of modern institutionalization (nineteenth century-World War II). Nationalities Papers, 33(2), 155-210.

Lăzurică, G. A. (1937a, September 10). În loc de Pagina Religioasă [Instead of the religious page]. Tara Noastră: Ediție specială săptămânală pentru Romii din România, 1(5/6), pp. 3-4.

Lăzurică, G. A. (1937b, July 25). Organizația Cetățenească a Romilor din România: Manifest [The citizen organisation of Roma in Romania: Manifesto]. Tara Noastră: Ediție specială săptămânală pentru Romii din România, 1(3), p. 6.

Lăzurică, G. A. (1938, February 28). Ce trebue să ştie Romii [What Roma should know]. Timpul. Oficiosul romilor din România, 6(69), p. 2.

Lăzurică, G. A., \& Șerboianu, C. I. P. (1937, August 1). Scrisoare deschisa d-lor A. C. Cuza si Octavian Goga [Open letter to A. C. Cuza and Octavian Goga]. Tara Noastră: Ediție specială săptămânală pentru Romii din România, 1(4), p. 1.

Lenghescu-Cley, N. (1934, November 1-15). Frați Romi [Roma brothers]. Glasul Romilor, 1(1), p. 1.

Marushiakova, E., \& Vesselin, P. (2000). Myth as process.
In T. Acton (Ed.), Scholarship and the Gypsy struggle: Commitment in Romani studies (pp. 81-93). Hatfield: University of Hertfordshire Press.

Marushiakova, E., \& Vesselin, P. (2017). Commencement of Roma civic emancipation. Studies in Arts and Humanities, 3(2), 31-55.

Matei, P. (2010). Raporturile dintre organizațiile țigăneşti interbelice şi Biserica Ortodoxă Română [The relations between the interwar Gypsy organisations and the Romanian Orthodox Church]. In V. Ciobanu \& S. Radu (Eds.), Partide politice şi minorități naționale din România în secolul XX [Political parties and national minorities in Romania in the 20th century] (Vol. V, pp. 159-173). Sibiu: Techno Media.

Matei, P. (2011). Romii în perioada interbelică: Percepții naționaliste [Roma in the interwar period: Nationalist perceptions]. In Ş. Toma \& L. Foszto (Eds.), Spectrum: Cercetări sociale despre romi [Spectrum: Social research on Roma] (pp. 15-40). Cluj-Napoca: Editura ISPMN and Kriterion.

Matei, P. (2012). Romi sau țigani? Etnonimele: Istoria unei neînțelegeri [Roma or Gypsies? Ethnonyms: The history of a misunderstanding]. In I. Horvath \& L. Nastasă (Eds.), Rom/Rrom sau țigan: Dilemele unui etnonim în spațiul românesc [Rom/Roma or Gypsy: Dilemmas of an ethnonym in the Romanian space] (pp. 13-73). Cluj: Editura ISPMN.

Matei, P. (2013). Documente de arhivă despre adunările țiganilor din Transilvania din anul 1919 [Archival documents concerning the Gypsies' assemblies in Transylvania in 1919]. Anuarul Institutului de Istorie "George Barițiu" din Cluj-Napoca, LII(Suppl.), 447-470.

Naftanailă, L. (1934, February). Către toți țiganii din Ardeal! [To all Gypsies in Transylvania!]. Neamul Țigănesc, 1(1), p. 1.

Nastasă, L., \& Varga, A. (2001). Minorități etnoculturale: Mărturii documentare, Tiganii din România (1919-1944) [Ethnocultural minorities: Documentary testimonies, Gypsies in Romania (1919-1944)]. Cluj: Fundatia CRDE.

Nicolăescu, N. (1934, January 21). Țiganii din România: Cine au fost? Cine sunt? Ce vor să fie? [Gypsies in Romania. Who were they? Who are they? What do they want to become?]. Timpul: Ziarul țiganilor din România, 3(24/25), pp. 1-2.

Niculescu, G. (1935, August). Scopul pentru care s'a creiat Asociația noastră [The purpose for which our Association was created]. Glasul Romilor, 2(1), p. 3.

Niculescu, G. (1937, May 5). Ne trebuesc apostoli [We need apostles]. Glasul Romilor, 2(4), p. 1.

Pantazescu, T. (1938, June 8). Meserii cari dispar [Trades that are disappearing]. Glasul Romilor, 3(11), p. 3.

Puxon, G. (1979). Einhundert Jahre Nationalbewegung der Zigeuner [A century-long national movement of Gypsies]. In T. Zülch (Ed.), In Auschwitz vergast, bis heute verfolgt: Zur Situation der Roma (Zigeuner) in Deutschland und Europa [Gassed in Auschwitz, per- 
secuted to this day: The situation of the Roma (Gypsies) in Germany and Europe] (pp. 290-300). Hamburg: Rowohlt.

Renegații [The renegades]. (1937, September 10). Tara Noastră: Ediție specială săptămânală pentru Romii din România, 1(5/6), p. 5.

Scrisoare [Letter]. (1926, February). Archival Holding Sabin Manuilă (File I.159/1926, pp. 16-17). Central National Historical Archives, Bucharest, Romania.

Scurtu, I., \& Dordea, I. (1996). Minoritățile naționale din România 1925-1931 [National minorities in Romania
1925-1931]. Bucharest: Romanian National Archive. Şerboianu, C. I. P. (1930). Les Tsiganes: Histoireethnographie-linguistique-grammaire-dictionnaire [Gypsies: History-ethnography-linguistics-grammardictionary]. Paris: Payot.

Simion, I. M. (1934, October 22). Suntem la datorie [We are on duty]. $O$ Róm, 1(2), p. 1.

Stan, V. (1938, June 8). Romii ardeleni [Transylvanian Roma]. Glasul Romilor, 3(11), p. 4.

Un milion! [A million!]. (1934, July 29). Timpul: Oficiosul romilor din România, 3(41), p. 1.

\section{About the Author}

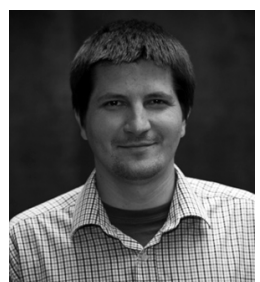

Petre Matei is a researcher at the "Elie Wiesel" National Institute for the Study of the Holocaust in Romania and an Associate Lecturer within the Department of Political Sciences, SNSPA, Bucharest. He holds a PhD in History with a thesis on the history of Roma in Romania in the first half of the 20th century with an emphasis on the Roma movement. His current research revolves around the Roma movement in interwar Romania, genocide and memorialisation. 